\title{
Adoption Levels Against Farmer Cultivation Technology Soybean (Glycine Max L) On the Influence of Socio-economic foundation in the District of South Kualuh North Labuhan Batu Regency
}

\author{
Iman Arman ${ }^{1 *}$, Fitra Syawal Harahap ${ }^{2}$ \\ ${ }^{1}$ Plantation Study Program, Medan Agricultural Development Polytechnic (Polbangtan) \\ ${ }^{2}$ Agrotechnology Study Program, Faculty Of Science And Technology, Labuhanbatu University. \\ *Corresponding Author \\ Email : Iman.arman71@gmail.com
}

\begin{abstract}
.
In running a farming business in an agricultural production organization, farmers as actors and implementers carry out organizing agricultural cultivation, labor, and capital aimed at production in the agricultural field, whether based on profit or not. Cultivation of soybean (Glycine max L.) is the main commodity of legumes which is a national mainstay because the source of vegetable protein is important for food diversification in supporting national food security. Many factors influence farmers in farming, especially in terms of prioritizing optimal production results, including economic factors with capital control so that the expectation of greater profits from farming will be chosen when compared to other forms of farming. The research objective was to determine the level of farmer adoption of soybean cultivation technology and to determine the socioeconomic effect of farmers on soybean cultivation technology in Sidua Dua Village, Kualuh Selatan District, North Labuhanbatu Regency. This research uses descriptive or quantitative methods by conducting survey methods. From the results of the study, it was found that the Farmer's Adoption Rate of Soybean Cultivation Technology (Glycine Max L) on the Influence of Socio-Economic Aspects in Kualuh Selatan District, North Labuhanbatu Regency was classified as moderate, soybean cultivation had not followed all the components of cultivation technology recommended by Field Agricultural Instructor and the level of adoption of soybean cultivation in Sidodadi village is influenced by age, level of education, length of farming, frequency of attending counseling.
\end{abstract}

Keywords: Soybean, socio-economy, farming, Kualuh Selatan Distric

\section{INTRODUCTION}

Indonesia is one of the developing countries with the agricultural sector as the livelihood of the majority of its population. The agricultural sector in the national development system plays an important role because in addition to providing food for the entire population it is also a contributing factor to the State's foreign exchange from the non-oil and gas sector [1].

Farming is a production organization, farmers act as executors to organize land (nature), labor, and capital aimed at production in the agricultural field, whether based on profit or not [3]. Farming is said to be successful if it can generate income to pay for all the costs and tools needed, in other words, the success of a farm is closely related to the income and costs incurred [4]. The ability to produce agricultural food products is determined by various factors, including biophysical, social, economic, and political [5].

In the future, the projected demand for soybeans will continue to increase in line with the increase in soybean consumption by the Indonesian people considering several considerations such as increasing population, increasing per capita income, public awareness of food nutrition. Per capita consumption from $8.12 \mathrm{~kg}$ in 2005 to $9.46 \mathrm{~kg}$ in 2020, an average increase of 1.02 percent per year [6].

Soybean (Glycine max L.) is one of the main commodities of legumes which is a national mainstay because it is an important source of vegetable protein for food diversification in supporting national food security. Every year, the need for soybeans reaches 2 million tons, while domestic soybean production is only 0.8 million tons per year so that to meet it requires imports of 1.2 million tons per year [7]. Many factors influence farmers in farming, especially In terms of prioritizing optimal production results, including economic factors, namely control of the capital, the expectation of greater profits from the farm to be 
selected when compared to other forms of farming, plant age, stability of production, whether or not these products are easily sold at any time [8 ]. Technical factors include the quality and area of land owned, commodity resistance to pests and diseases, production potential, degree of adaptation, and climate suitability [9]. Social factors include long-standing traditions and habits, neighboring farming, availability of labor, interests of farmers and their families, level of education, and so on [10].

In the implementation of the production process on a farm, farmers are faced with internal and external problems, internal problems including limited production factors, both quality, and quantity [11]. Thus farmers must be clever in selecting and coordinating the types of plants that are profitable and combining the existing production factors so that they can generate maximum income [12]. Meanwhile, external problems are natural conditions or seasons as well as pests and diseases [13].

Along with soybean farming, it is necessary to have an adoption process in an agricultural commodity. The adoption process is preceded by the introduction of an innovation (introduction) to the farming community, then a mental process occurs to accept or reject the innovation [14]. If the result of this mental process is a decision to accept innovation, there will be adoption. [15]. The adoption process occurs through several stages, namely awareness, attention, assessment, trial, adoption, confirmation [16]. The purpose of this study was to determine the level of farmer adoption of soybean cultivation technology and to determine the socio-economic effect of farmers on soybean cultivation technology in Sidua Dua Village, Kualuh Selatan District, North Labuhanbatu Regency.

\section{METHODS}

This research was conducted in Sidua Dua Village, Kualuh Selatan District, North Labuhanbatu Regency. The research was conducted from October 2020 to April 2021. This research was carried out using descriptive methods or quantitative methods by conducting a survey method for soybean farmers in the area of Siduadua Village, Kualuh Selatan District, North Labuhanbatu Regency.

\section{RESULTS AND DISCUSSION}

\section{Farmer's Adoption Rate of Soybean Cultivation Technology}

The adoption rate of soybean cultivation technology in Sidua Dua Village, Kualuh Selatan District, North Labuhanbatu Regency can be seen in Table 1 below. From Table 1 it can be seen that not all soybean cultivation technology has been applied by farmers, the highest percentage of achievement was obtained in varieties, namely $83.33 \%$ with an average of 2.80 while the lowest was fertilization with a percentage of $37.66 \%$ with an average score of 1.13 while from the overall average was 15.03 with a percentage of 63.33 . Table 1 above shows that the level of adoption of soybean cultivation technology in the study area can be categorized as moderate. This is because the research areas are still using traditional agricultural systems in addition to expensive fertilizers, insufficient capital, the lack of the role of extension workers and there is no clear socialization from the local government so that the level of farmer adoption of soybean cultivation technology is in the medium category.

Table 1. The Adoption Rate of Soybean Cultivation Technology in Sidua Dua Village, Kualuh Selatan District, North Labuhanbatu Regency.

\begin{tabular}{llllll}
\hline No & Cultivation technology & $\begin{array}{l}\text { Average } \\
\text { achieved }\end{array}$ & score & $\begin{array}{l}\text { Expected } \\
\text { score }\end{array}$ & $\begin{array}{l}\text { Percentage } \\
\text { fatigue (\%) }\end{array}$ \\
\hline 1 & Varieties & 2,80 & 3 & 83.33 \\
2 & Land processing & 2,70 & 3 & 73.33 \\
3 & Planting & 2,21 & 3 & 63.33 \\
4 & Maintenance & 1,80 & 3 & 50.00 \\
5 & Fertilization & 1,57 & 3 & 52.33 \\
6 & Pest control & 1,48 & 3 & 37.66 \\
7 & Harvest and Post-harvest & 2,47 & 3 & 81.00 \\
& Sum & $\mathbf{1 5 , 0 3}$ & $\mathbf{2 1}$ & $\mathbf{6 3 . 3 3}$ \\
\hline
\end{tabular}


Table 2. Regression Results for Socio-Economic Aspects with Farmer Adoption Rates

\begin{tabular}{|c|c|c|c|c|}
\hline \multirow{2}{*}{ No } & \multirow{2}{*}{ Variabel } & \multicolumn{3}{|c|}{ Socio-Economic Aspects of Farmers } \\
\hline & & Coefficient & T-Count & T-Table \\
\hline 1 & Constant & 7235476.027 & 1.643 & \multirow{7}{*}{2.08} \\
\hline 2 & $\operatorname{Age}\left(X_{1}\right)$ & 434.941 & 3.122 & \\
\hline 3 & Level of education $\left(\mathrm{X}_{2}\right)$ & 64.156 & 2.998 & \\
\hline 4 & The duration of trying $\left(\mathrm{X}_{3}\right)$ & 176.765 & 2.580 & \\
\hline 5 & $\begin{array}{l}\text { Frequency of Attending Counseling } \\
\left(\mathrm{X}_{4}\right)\end{array}$ & 0.111 & 0.038 & \\
\hline 6 & The number of dependents $\left(\mathrm{X}_{5}\right)$ & 0.318 & 1.632 & \\
\hline 7 & Land area $\left(\mathrm{X}_{6}\right)$ & 1.565 & 0.311 & \\
\hline & $\mathrm{R}^{2}$ & 0.776 & & \\
\hline & Rsquare & 0.878 & & \\
\hline & Ajusted RSquare & 0.876 & & \\
\hline & F-hitung & 8.145 & & \\
\hline & F-tabel & 2.74 & & \\
\hline & Standar Error & 5043453.235 & & \\
\hline
\end{tabular}

Soybean cultivation technology adopted by farmers comes from field agricultural extension workers where field agricultural extension workers are tasked with providing information on planting technology, maintenance, fertilization, and good pest and disease control for soybean cultivation such as the use of superior varieties, how to cultivate soybean soil, planting distance and correct in managing soybean farming so that it has a positive impact on the production and income of farmers. However, in Sidua Dua Village, Kualuh Selatan District, North Labuhanbatu Regency, the performance and role of extension personnel is still less than the task that should be carried out where the farmers do not feel the role of the instructor. Besides that, farmers also think that they know better what they are doing because farmers feel they have been doing the farming for longer.

\section{The Influence of Socio-Economic Aspects of Farmers and Farmer's Adoption Rate of Soybean Cultivation Technology.}

The regression results from the influence of the socio-economic aspects of farmers with the level of farmer adoption on soybean cultivation technology in Sidua Dua Village, Kualuh Selatan District, North Labuhanbatu Regency can be seen in Table 2 above.

From Table 2 above, it is found that F count (8.136)> F table (2.74) so that simultaneously the variables of age, level of education, length of farming, frequency of attending counseling, number of dependents, land area have a positive effect on the adoption of soybean cultivation technology. The $\mathrm{R}^{2}$ coefficient shows 0.752 , which means that the variation of the ups and downs of soybean cultivation technology is influenced by age, level of education, length of farming, frequency of attending counseling, number of dependents, and a land area of $75 . \%$ while the remaining $24.8 \%$ is influenced by other variables not estimated in the study this.

\section{CONCLUSION}

The adoption rate of soybean cultivation in Sidua Dua Village, Kualuh Selatan District, North Labuhanbatu Regency is classified as moderate for soybean cultivation in the Sidodadi village area and has not followed all the components of cultivation technology recommended by field agricultural extension workers so that the adoption rate of soybean cultivation in Siduadua village is influenced by age, level of education, length of farming, frequency of attending counseling while the number of dependents and the land area did not affect the adoption rate of soybean cultivation technology.

\section{REFERNCES}

[1] Elisabeth, D.A.A., Harsono, A., Sundari, T. And Nugrahaeni, N., 2020. Financial Analysis of Application of Biodiversity Soybean Cultivation Technology in Rainfed Rice Fields. Jurnal Pengkajian Dan Pengembangan Teknologi Pertanian, 22(1), Pp.15-26. 
[2] Septiadi, D., Suparyana, P.K. And Fr, A.F.U., 2020. Analysis of Income and Effect of Use of Production Inputs on Soybean Farming in Central Lombok Regency. Jia (Jurnal Ilmiah Agribisnis): Jurnal Agribisnis Dan Ilmu Sosial Ekonomi Pertanian, 5(4), Pp.141-149.

[3] Budiraharjo, K., Nurfadillah, S. And Roessali, W., 2020. Soybean Value Chain Performance in Grobogan Regency. Jurnal Agrisep Kajian Masalah Sosial Ekonomi Pertanian Dan Agribisnis, Pp.347-360.

[4] Kurniawan, A.Y., 2012. Factors Affecting Technical Efficiency in Tidal Land Rice Farming in Anjir Muara District, Barito Regency, Kuala Kalimantan Selatan. Agrides: Jurnal Agribisnis Perdesaan, 2(1), P.9263.

[5] Kardiyono, M., Indastri, N.S., Yuliasih, I. And Pramuhadi, G., 2018. Strategy for Increasing the Productivity and Quality of Local Soybean with a Green Productivity Approach. Journal Of Agroindustrial Technology, 28(3).

[6] Latifah, E., Dewi, H.A., Daroini, P.B., Zakariya, A.Z., Hakim, A.L. And Mariyono, J., 2018. Test Technical And Economical component of Integrated Pest Management Disease On Farm Tomato. Agrovigor: Jurnal Agroekoteknologi, 11(1), Pp.1-8.

[7] Nababan, D.F.I.S.B., Lifianthi, L. And Rosana, E., 2020. The Performance of Farmer Groups in Supporting Irrigation Rice Farming Income in Hutanauli Village, Dolok Masihul District, Serdang Bedagai Regency (Doctoral Dissertation, Sriwijaya Universiy).

[8] Suyatno, A., Imelda, I. And Komariyati, K., 2018. The Effect Of Tractor Utilization On Revenue And Use Of Labor On Rice Farming In Sambas Regency. Agraris: Journal Of Agribusiness And Rural Development Research, 4(2), Pp.92-100.

[9] Andajani, W. And Sidhi, E.Y., 2019. Efficiency of Black Soybean Farming through Partnership Patterns with Cooperatives (Case Study in Sumberagung Village, Gondang District, Nganjuk Regency). Jurnal Agrinika: Jurnal Agroteknologi Dan Agribisnis, 3(2), Pp.120-133.

[10] Hidayat, Y., Lala, F., Suwitono, B., Aji, H.B. And Bram, D., 2020. Implementation Technology To Productivity Increase At Dryland Under Coconut In North Maluku. Buletin Palma Volume, 21(1), Pp.11-21.

[11] Wicaksono, M. And Harahap, F.S., 2020. The Effect of the Interaction of Rhizobium and Nitrogen Fertilization Treatments on Harvest Index of Three Soybean Varieties. Jurnal Tanah Dan Sumberdaya Lahan, 7(1), Pp.39-44.

[12] Pakpahan, T.E., Pasaribu, A. and Wicaksono, M., 2020. Farmer Adoption and Factors Affecting Non-Seed Watermelon (Citrullus lanatus) Farming in Sei Mencirim Village. Jurnal AGROHITA: Jurnal Agroteknologi Fakultas Pertanian Universitas Muhammadiyah Tapanuli Selatan, 5(2), pp.129-142.

[13] Adriansyah, A. and Wahyuni, H., 2020. The Influence of Socio-Economic Aspects with the Level of Farmers' Adoption of Soybean Cultivation Technology (Glycine Max L) in Baringin District, Deli Serdang Regency. Al Ulum, 8(1), pp.24-27.

[14] Suyatno, A., Imelda, I. and Komariyati, K., 2018. The Effect of Tractor Utilization on Revenue and Use of Labor on Rice Farming in Sambas Regency. AGRARIS: Journal of Agribusiness and Rural Development Research, 4(2), pp.92-100.

[15] Ginting, E. and Tastra, I.K., 2013. Soybean Quality Standards. Soybean: production and development techniques: Food Crops Research and Development Center. Available from : http://balitkabi. litbang. pertanian. go. id/wpcontent/uploads/2016/03/dele_19. erli_pdf. 